\title{
Газохроматографический анализ жирных кислот фосфолипидов растений кукурузы в условиях разной аэрации
}

\author{
(C) 2020 Ершова А.Н. ${ }^{1}$, Тюрина И.В. $^{2}$ \\ ${ }^{1}$ ФББОУ ВО «Воронежский государственный педагогический университет», Воронеж \\ ${ }^{2}$ ФББУ ВО «Воронежский государственный университет», Воронеж
}

Поступила в редакцию 31.01.2020 г.

DOI: $10.17308 /$ sorpchrom.2020.20/2774

Липиды являются важнейшим структурным, запасным и функциональным компонентом растительных клеток. При этом фосфолипиды, относящиеся к полярным липидам, являются интегральными компонентами клеточных мембран, определяя вместе с белками их структуру и функции. В тоже время работ, посвященных изучению влияния дефицита кислорода на содержание липидов и их жирнокислотный состав, в связи со сложностью методов изучения этих компонентов растительных клеток, крайне мало. Исследовали методом газожидкостной хроматографии состав и динамику изменения содержания жирных кислот в фосфолипидах проростков кукурузы, подвергшихся воздействию кратковременной (3-24час.) гипоксии. Липиды экстрагировали после фиксации проб кипящим изопропанолом смесью гексан : изопропанол (3:2). Фосфолипиды из липидной фракции выделяли методом тонкослойной хроматографии. Гидролиз фосфолипидов и метилирование жирных кислот проводили в запаянных ампулах при $+100^{\circ} \mathrm{C}$ в течение 2 часов. Газохроматографический анализ показал, что в фосфолипидах проростков кукурузы доминирующими среди жирных кислот были пальмитиновая (C16:0) и линолевая С18:2) кислоты, содержание которых составляло 27.39 и $54.78 \%$ от суммы всех кислот. При дефиците кислорода в первые 3-6 часов содержание диеновой С18:2 кислоты в фосфолипидах снижалось, при этом индекс ненасыщенности (ИН) жирных кислот уменьшался с 1.15 (аэрация) до 0.96. Уменьшение в фосфолипидах проростков кукурузы при гипоксии содержания ненасыщенных жирных кислот могло быть обусловлено деструкцией фосфолипидов или усилением процессов перекисного окисления их жирных кислот под действием липоксигеназ. К 24 часам гипоксии содержание С18:2 возрастало до уровня аэрируемых растений, вероятно за счет усиления синтеза. ИН жирных кислот фосфолипидов повышался, но оставался еще ниже аэрируемых растений , так как снижалось содержание пальмитолеиновой (C16:1) кислоты с 7.74 до $0.92 \%$ и возрастало пальмитиновой (C16:0) кислоты до $29.17 \%$. Проведенные исследования показали, что изменения в составе жирных кислот фосфолипидов растений, попадающих в условия дефицита кислорода (гипоксия) начинают проявляться уже при достаточно коротких, часовых экспозициях (3-6 час), а не многосуточных, как ранее отмечалось. Предполагается, что восстановление уровня ненасыщенности жирных кислот фосфолипидов позволяет проросткам кукурузы, относящимся к среднеустойчивым растениям, в условиях кратковременного дефицита кислорода стабилизировать структуру и свойства биологических мембран, что повышает их адаптационные возможности.

Ключевые слова: фосфолипиды, жирные кислоты, газожидкостная хроматография, гипоксия, проростки кукурузы.

\section{Введение}

Липиды являются важнейшим структурным, запасным и функциональным компонентом растительных клеток. По своей химической структуре группа природных липидов многочисленна и гетерогенна. Липиды, как и другие компоненты живых систем, находятся в состоянии постоянного динамического равновесия [1]. Полярные 
липиды, включающие фосфолипиды, являются интегральными компонентами клеточных мембран, определяя вместе с белками их структуру и функции [2]. Факторы внешней среды оказывают существенное влияние на состав и свойства липидов растений $[3,4]$. Уменьшение содержания суммарных липидов, в основном за счет группы полярных липидов, отмечалось при анаэробном выращивании разных видов ириса, устойчивого и неустойчивого к аноксии [5], проростках пшеницы и риса [6,7]. Как известно, гетерогенность фосфолипидов в основном определяется особенностями их жирнокислотного состава. Из двух жирных кислот в лецитинах (фосфотидилхолины) одна, насыщенная, находится в $\alpha$-положении, другая, ненасыщенная, в $\beta$-положении [6]. Работы, посвященные изучению влияния дефицита кислорода на содержание липидов и их жирнокислотный состав, в связи со сложностью методов исследования этих компонентов растительных клеток, крайне немногочисленны [8]. Проведенные исследования касались влияния достаточно длительных (многосуточных) экспозиций для небольшого количества растений [6-8]. В то же время ранее нами было показано [9], что уже при кратковременном нахождении растений кукурузы в условиях гипоксии (до суток) отмечались изменения в фонде свободных жирных кислот митохондрий за счет увеличения содержания ненасыщенных кислот. Авторы предположили, что это могло быть результатом распада фосфолипидных компонентов мембран растений, усиливающегося в клетках при дефиците кислорода. В связи с этим методом газожидкостной хроматографии исследовали динамику изменения жирнокислотного состава фосфолипидов растений, которые находились в условиях аэрации и кратковременной гипоксии.

\section{Эксперимент}

В качестве объекта исследования использовались 10-12 дневные проростки кукурузы (Воронежская 76), выращенные методом гидропоники. Этиолированные проростки без корней и семядолей помещали на 3-24 часа в затемненные вакуум-эксикаторы, через которые пропускали разные газовые среды: воздух (контроль) или азот (содержание кислорода менее $1.0 \%$ v/v) из баллона.

Липиды экстрагировали после фиксации проб кипящим изопропанолом смесью гексан : изопропанол (3:2). Для предотвращения окислительного распада липидов экстрагирование проводили в присутствии антиоксиданта ионола (0.001\%). Водорастворимые примеси отделяли обработкой проб раствором $1 \% \mathrm{Na}_{2} \mathrm{SO}_{4}$ из расчета $1 \mathrm{~cm}^{3}$ на $2 \mathrm{~cm}^{3}$ липидного экстракта. После интенсивного встряхивания (1-2 мин) верхний гексановый слой, содержащий липиды, отделяли и упаривали на роторном испарителе при $+40-45^{\circ} \mathrm{C}$. Полученную липидную фракцию растворяли в 2$3 \mathrm{~cm}^{3}$ хлороформа [10].

Выделение фосфолипидов из липидной фракции проводили методом тонкослойной хроматографии на пластинках с силикагелем W с добавлением 5\% гипса («Merk» Германия). Перед использованием пластинки активировали в течение 1 часа при $+110^{\circ} \mathrm{C}$. На подготовленные пластинки наносили 0.05-0.1 $\mathrm{cm}^{3}$ липидного экстракта. Хроматографическое разделение липидов проводили в растворителе ацетон : уксусная кислота : вода в соотношении 100:2:1 [11]. После хроматографического разделения и высушивания, присутствие на пластинках липидных фракций определяли в парах йода. Идентификацию липидных фракций проводили так же по величине $\mathrm{R}_{\mathrm{f}}$ и свидетелям. В данной системе растворителей фосфолипиды оставались на старте, $\mathrm{R}_{\mathrm{f}}$ для нейтральных липидов составила 0.89 , сульфолипидов -0.78 , галактолипидов -0.20 . Выделенные фосфолипиды переносили в ампулы для гидролиза и метилирования.

$\boldsymbol{E}$ ршова и др. / Сорбционные и хроматографические процессы. 2020. Т. 20. № 2. С. 207-214 
Гидролиз и метилирование проводили в стеклянных запаянных ампулах, куда к фракции фосфолипидов добавляли $4 \mathrm{~cm}^{3}$ метилирующей смеси метанол:серная кислота (19:1). Метилирование проводили при температуре $+100^{\circ} \mathrm{C}$ в течение 2 часов. После гидролиза содержимое ампулы переносили в пробирки с пришлифованными пробками и разбавляли водой $\left(1 \mathrm{~cm}^{3}\right)$. Метиловые эфиры жирных кислот экстрагировали гексаном при энергичном встряхивании пробирок (1-2 мин). Верхний гексановый слой собирали и упаривали в токе азота при $+40^{\circ} \mathrm{C}$, доводя объем до $0.5 \mathrm{~cm}^{3}$.

Метиловые эфиры жирных кислот анализировали методом газожидкостной хроматографии на приборе «Chrom 42» (Чехия) в изотермическом режиме с пламенноионизационным детектором и колонкой $(0.5 \times 2.5 \mathrm{M})$, заполненной $10 \%$ полиэтиленгликольсукцинатом на хроматоне N-AW («Chemapol», Чехия). Температура камеры испарения составляла $+220^{\circ} \mathrm{C}$, термостата $-+190^{\circ} \mathrm{C}$. Скорость газа носителя (гелия) и водорода составляла $40 \mathrm{~cm}^{3} /$ мин, воздуха $-300 \mathrm{~cm}^{3} / \mathrm{мин} \mathrm{[9].}$

Пики метиловых эфиров жирных кислот идентифицировали по времени удерживания на колонке в сравнении со стандартным набором. Стандартная смесь К101 Mixture Zot 1314 («Sigma», CША), включала метиловые эфиры каприловой (C8:0), каприновой (C10:0), лауриновой (C12:0), миристиновой (C14:0), пальмитиновой $(\mathrm{C} 16: 0)$, стеариновой (C18:0) и арахиновой (С20:0) кислот. Использовали и смесь метиловых эфиров пальмитиновой (C16:0), стеариновой (C18:0), олеиновой (C18:1) и линолевой (C18:2) кислот («Serva», Германия). Содержание каждой кислоты выражали в относительных величинах. Рассчитывали площадь пиков всех кислот на хроматограмме и выражали содержание каждой кислоты в \% от суммы площадей всех обнаруженных кислот. Индекс ненасыщенности жирных кислот (ИН) рассчитывали по формуле $И Н=\Sigma P_{i} \mathrm{e}_{i} / 100$, где $P_{i}-$ содержание $i$-той ЖК $(\%), \mathrm{e}_{i}-$ число связей $i$-той жирной кислоты. Определяли и соотношение ненасыщенных (u) и насыщенных (s) жирных кислот(u/s).

Опыты проводили в двух биологических и двух аналитических повторностях. Каждый эксперимент повторяли не менее 2-3 раз. В таблицах представлены данные одного из опытов в виде средних арифметических значений и их стандартных отклонений, подсчитанных с помощью пакета программ Microsoft Excel.

\section{Обсуждение результатов}

Как известно [6,12], именно жирные кислоты липидов растений наиболее чутко реагируют на воздействие разных факторов внешней среды и их метаболизм находится в прямой зависимости от ее газового состава. Исследовали состав жирных кислот липидов проростков кукурузы, экспонированных в течение 3-24 часов в условиях разных газовых сред. Выделенные из суммарных липидов растений методом тонкослойной хроматографии фосфолипиды подвергали метанолизу и образовавшиеся метиловые эфиры жирных кислот анализировали газохроматографическим методом. Идентификацию пиков проводили в соответствии со временем удерживания на колонке и хроматографическим разделением стандартного набора метиловых эфиров жирных кислот. В таблице 1 приведено содержание основных жирных кислот, присутствующих в фосфолипидах. Доминирующими были пальмитиновая (C16:0) и линолевая кислоты, содержание которых составляло 27.39 и $54.78 \%$ от суммы всех кислот. Содержание остальных жирных кислот было гораздо меньше. Во фракции фосфолипидов присутствовала из насыщенных стеариновая (С18:0) - 2.07\% и арахиновая $(\mathrm{C} 20: 0)-10.08 \%$, а из ненасыщенных - пальмитолеиновая $(\mathrm{C} 16: 1)-2.50 \%$ и олеиновая (С18:1) - 2.59\% кислоты.

$\boldsymbol{E}$ ршова и др. / Сорбционные и хроматографические процессы. 2020. Т. 20. № 2. С. 207-214 
Таблица 1. Изменение состава жирных кислот фосфолипидов проростков кукурузы при разных сроках действия гипоксии (\% от суммы)

\begin{tabular}{|c|c|c|c|c|c|c|}
\hline \multirow{2}{*}{ Вариант } & \multicolumn{6}{|c|}{ Жирные кислоты } \\
\hline & $16: 0$ & $16: 1$ & 18:0 & $18: 1$ & $18: 2$ & $20: 0$ \\
\hline \multicolumn{7}{|c|}{ Воздух } \\
\hline \multirow{2}{*}{3 ч } & $27.39 \pm$ & $2.50 \pm$ & 2.07 & $2.59 \pm$ & $54.78 \pm$ & $10.08 \pm$ \\
\hline & 0.29 & 0.08 & 0.01 & 0.19 & 0.11 & 0.22 \\
\hline \multirow{2}{*}{6 ч } & $27.81 \pm$ & $2.24 \pm$ & $1.85 \pm$ & $2.55 \pm$ & $5467 \pm$ & $8.40 \pm$ \\
\hline & 2.06 & 0.11 & 0.01 & 0.25 & 1.34 & 0.35 \\
\hline \multirow{2}{*}{9 ч } & $27.83 \pm$ & $2.90 \pm$ & $2.42 \pm$ & $1.82 \pm$ & $53.09 \pm$ & $10,72 \pm$ \\
\hline & 0.35 & 0.01 & 0.01 & 0.82 & 0.23 & 0.13 \\
\hline \multirow{2}{*}{24 ч } & $28.03 \pm$ & $1.90 \pm$ & $1.12 \pm$ & $2.82 \pm$ & $53.29 \pm$ & $12,02 \pm$ \\
\hline & 0.35 & 0.01 & 0.01 & 0.02 & 0.23 & 0,13 \\
\hline \multicolumn{7}{|c|}{ Гипоксия } \\
\hline \multirow{2}{*}{3 ч } & $24.62 \pm$ & $7.54 \pm$ & $4.12 \pm$ & $1.14 \pm$ & $43.78 \pm$ & $10.10 \pm$ \\
\hline & 0.02 & 0.02 & 0.07 & 0.02 & 0.36 & 0.02 \\
\hline \multirow{2}{*}{6 ч } & $24.94 \pm$ & $4.94 \pm$ & $4.01 \pm$ & $1.29 \pm$ & $45.74 \pm$ & $9.56 \pm$ \\
\hline & 0.19 & 0.14 & 0.06 & 0.23 & 0.20 & 0.04 \\
\hline \multirow{2}{*}{9 ч } & $23.21 \pm$ & $3.39 \pm$ & $5.00 \pm$ & $1.42 \pm$ & $52.86 \pm$ & $14.11 \pm$ \\
\hline & 0.27 & 0.16 & 0.34 & 0.01 & 0.90 & 0.12 \\
\hline \multirow{2}{*}{24 ч } & $29.17 \pm$ & $0.92 \pm$ & $2.09 \pm$ & $1.29 \pm$ & $53.53 \pm$ & $12.09 \pm$ \\
\hline & 0.09 & 0.09 & 0.16 & 0.07 & 0.57 & 0.70 \\
\hline
\end{tabular}

В условиях дефицита кислорода в фосфолипидах присутствовали те же жирные кислоты, что и у растений, находящихся в условиях нормальной аэрации (рис.1).

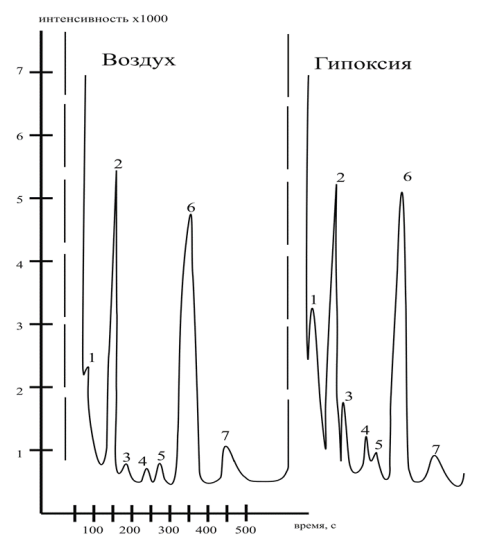

Рис.1 Хроматограмма жирных кислот фосфолипидов проростков кукурузы при действии разных газовых сред: 1 - миристиновая (C14:0), 2 - пальмитиновая

(C16:0), 3 - пальмитолеиновая (C16:1), 4 - стеариновая (С18:0), 5 - олеиновая

(C18:1), 5 - линолевая (С18:2), 7 - арахиновая (С20:0) кислоты

Начиная с первых часов в фосфолипидах проростков, экспонированных в условиях гипоксии, существенно снижалось содержание ненасыщенных жирных кислот с одной и двумя связями - олеиновой (С18:1) и, особенно, линолевой (С18:2) кислот. Содержание диеновой линолевой кислоты в первые три часа действия гипоксии уменьшалось с 54.78 до 43.78\%. Содержание моноеновой пальмитолеиновой кислоты (C16:1) при этом наоборот, увеличивалось с 2.50 до 7.54\%. Снижалось содержание насыщенной пальмитиновой кислоты (C16:0) с 27.39 до 24.62\%, и повышалось содержание стеариновой кислоты $(\mathrm{C} 18: 0)$ до $4.12 \%$. В результате подобных изменений в 
первые три часа действия гипоксии в фосфолипидах отношение ненасыщенные/насыщенные (u/s) жирные кислоты, которое, как считают [6,10], свидетельствует о стойкости растений к повреждающему фактору, снижалось с 1.57 (аэрация) до 1.35 при гипоксии. К 24 часам у проростков кукурузы, находившихся в условиях гипоксии, содержание линолевой кислоты в фосфолипидах постепенно возрастало, однако отношение u/s, также как и показатель ненасыщенности жирных кислот (ИН), оставались ниже, чем у аэрируемых растений (табл.2).

Таблица 2. Содержания основных групп жирных кислот фосфолипидов проростков кукурузы в условиях разной аэрации (\% от суммы кислот, $S$-насыщенные кислоты, $U$-ненасыщенные кислоты, $И Н$-индекс ненасыщенности)

\begin{tabular}{|c|c|c|c|c|}
\hline \multirow{2}{*}{ Вариант } & \multicolumn{4}{|c|}{ Жирные кислоты фосфолипидов } \\
\cline { 2 - 5 } & $U$ & $S$ & $U / S$ & ИН \\
\hline \multicolumn{5}{|c|}{ Воздух } \\
\hline 3 ч & 59.8 & 39.5 & 1.52 & 1.15 \\
\hline 6 ч & 59.5 & 37.8 & 1.59 & 1.14 \\
\hline 9 ч & 57.8 & 40.9 & 1.42 & 1.10 \\
\hline 24 ч & 58.0 & 41.2 & 1.41 & 1.11 \\
\hline \multicolumn{5}{|c|}{ Гипоксия } \\
\hline 3 ч & 52.5 & 38.8 & 1.35 & 0.96 \\
\hline 6 ч & 51.9 & 38.5 & 1.34 & 0.98 \\
\hline 9 ч & 57.7 & 42.3 & 1.36 & 1.10 \\
\hline 24 ч & 55.7 & 43.3 & 1.24 & 1.09 \\
\hline
\end{tabular}

Изменение ненасыщенности жирных кислот фосфолипидов при действии длительных сроков анаэробиоза (4-7 суток) отмечалось ранее $[5,7,8]$ и свидетельствует о том, что именно ненасыщенные жирные кислоты являются наиболее лабильным компонентом полярных липидов, к которым и относят фосфолипиды [13]. В наших опытах эти изменения наблюдались уже через3-6 часов действия гипоксического стресса.

\section{Заключение}

Метаболизм жирных кислоты липидов растений находится в прямой зависимости от газового состава окружающей среды [12]. При этом показана возможность синтеза липидов у растений в условиях недостаточного снабжения кислородом [7]. Предполагается [7,14], что за счет реакций синтеза липидов в клетках растений происходит регенерация восстановленных пиридиновых нуклеотидов, что позволяет функционировать циклу Кребса и гликолизу, как основных поставщиков АТФ.

В наших опытах в первые часы (3-6 ч) гипоксического стресса в проростках кукурузы наблюдалось накопление моноеновой пальмитолеиновой (С16:1) кислоты, а к концу опыта (24 ч.) восстанавливалось содержание и диеновой линолевой (C18:2) кислоты. Вероятно, это могло происходить за счет восстановления или даже усиления синтеза линолевой кислоты. Полученные нами результаты подтверждаются исследованиями $[2,14]$, в которых показано, что кроме линолевой, в анаэробно выращенных колеоптилях риса, при длительных экспозициях, могло возрастать содержание и олеиновой кислоты [7]. Увеличение количества ненасыщенных жирных кислот в фосфолипидах анаэробно выращенных колеоптилях риса наблюдали и другие исследователи [5,7]. Авторы также не исключали возможности синтеза как липидов, так и образование ненасыщенных жирных кислот с одной или двумя двойными связями в условиях недостаточного снабжения растений кислородом. Однако это характерно, по их мнению $[6,7,14]$, только для устойчивых к аноксии растений и на определенном этапе 
онтогенеза. В тоже время в проростках кукурузы, являющейся среднеустойчивой культурой, мы наблюдали это и при достаточно коротких сроках (до суток) действия гипоксии. Вместе с возрастанием содержания ненасыщенной линолевой кислоты в фосфолипидах растений отмечалось и увеличение количества насыщенной пальмитиновой кислоты. В связи с этим полного восстановления индекса ненасыщенности фосфолипидов $(И Н)$ и показателя $(\mathrm{u} / \mathrm{s})$ до уровня аэрируемых растений не происходило. Восстановление содержания только диеновой линолевой кислоты в фосфолипидах проростков.

В первые часы действия условий дефицита кислорода нельзя исключить усиления и процессов перекисного окисления жирных кислот липидов [15]. Активацию скорости свободнорадикальных процессов в условиях кратковременной гипоксии наблюдали ранее не только в наших опытах [16], но и в работах других исследователей $[17,18]$. С увеличением сроков действия отмечалась торможение процессов перекисного окисления липидов (ПОЛ) за счет ферментативного пути и усиления неферментативных реакций. Показано, что процессам ПОЛ подвергаются не только свободные, но и связанные в липидах жирные кислоты $[16,17]$. Уменьшение в фосфолипидах проростков кукурузы содержания ненасыщенных жирных кислот в условиях кратковременной гипоксии могло быть связано и с деструкцией фосфолипидов, что подтверждается накоплением в фонде свободных жирных кислот линолевой и пальмитолеиновой кислот [9]. Можно предположить, что в условиях гипоксии в фосфолипидах кукурузы содержание ненасыщенных жирных кислот на начальных этапах (3-6 ч) падало, что могло быть результатом как усилениям ПОЛ под действием липоксигеназы [19], так и деструкцией фосфолипидов. Однако при более длительных сроках анаэростатирования (24 ч) происходило усиление синтеза полиненасыщенных жирных кислот из моноеновых под действием соответствующих десатураз. [20].

Таким образом, проведенные нами исследования показали, что изменения в составе жирных кислот фосфолипидов растений, попадающих в условия дефицита кислорода (гипоксия), начинают проявляться уже при достаточно коротких, часовых экспозициях (3-6 час), а не многосуточных, как ранее отмечалось. Эти изменения выражались в уменьшения содержания полиеновых, в первую очередь линолевой кислоты, при сохранении скорости синтеза моноеновой пальмитолеиновой кислоты (C16:1). Однако к концу опыта (через 24 ч) синтез линолевой кислоты практически восстанавливался, в результате чего ИН жирных кислот фосфолипидов постепенно возрастал. Можно предположить, что восстановление уровня ненасыщенности жирных кислот фосфолипидов позволяет проросткам кукурузы, относящимся к среднеустойчивым растениям, в условиях кратковременного дефицита кислорода стабилизировать структуру и свойства биологических мембран, а также сохранять активность мембраносвязанных ферментов [21], что повышает их адаптационные возможности.

\section{Список литературы}

1. Грибанов Г.А. // Успехи современ. биологии. 1979. Т.87. № 1. С.16-33.

2. Harwood J.L. // INFORM: Int. News Fats, Oils and Relat. Mater. 1994. Vol.5. No 7. pp. 835-839.

3. Williams J.P., Mitchell K., Khan M., 1987, Metab. Skuct. and Funct. Plant Lipids", Proceedings, 7th Int. Sym. Plant Lipids, Davis New-York, London, pp. 433-436.
4. Попов В.Н., Антипина О.В., Пчёлкин В.П., Цыдендамбаев В.Д. //Физиология растений. 2017. Т. 64. № 2. С. 109-115

5. Crawford R.M.M., Walton J.C., Wollen B. // Proceedings of the Royal Society of Edinburg. 1994. Vol. 102B. pp. 325-332.

6. Chirkova T., Gobengishvili L., Hakala K. // Physiol. Plant. 1990. Vol. 79. No 2. pp. 132135. 
7. Генерозова И.Р., Вартапепян Б.Б. // $\Phi u$ зиология растений. 2005. Т. 52. № 4. С. 540548.

8. Behr J.H, Bouchereau A., Berardocco S., Seal C.E. et al. // Annals of Botany. 2017. Vol.119. pp. 965-976.

9. Ершова А.Н., Тюрина И.В. // Сорбиионные и хроматографические проųессы. 2018. Т.18. № 6. С. 927-933

10. Ершова А.Н. Метаболическая адаптация растений к гипоксии и повышенному содержанию диоксида углерода. Воронеж. Воронеж. гос. ун-т. 2007. 264 с.

11. Землянухин А.А., Ершова А.Н. // Доклады АН СССР. 1986. Т. 281. № 3. С. 762764.

12. Brown D., Beevers H. // Plant Physiol. 1987. Vol. 84. No 2. pp. 555-559.

13. Vartapetian B.B., Andreeva I.N., Generosova I.R. // Annals of Botany. 2003. Vol. 91.pp. $155-173$.
14. Fox T.C., Kennedy R.A., Rumpho M.E. // Annals of Botany. 1994. Vol. 74. No 3. pp. 445455.

15. Sconfeld P., Wojtczak L. // Free Rad Biol Med. 2008. Vol. 45. pp. 231-241.

16. Ершова А.Н., Попова Н.В., Бердникова О.С. // Физиология растений. 2011. Т. 58. № 6. C. $834-843$

17. Sasidharan R., Hartman S., Liu Z., Martopawico S. et al. // Plant Physiol. 2018. Vol. 176. No 2. pp. 1106-1117.

18. Blokhina O., Fagerstedt K.V. // Physiol. plantarum. 2010. Vol. 138. pp. 447-462.

19. Ivanov I. // Archives of Biochemistry and Biophysics. 2010. Vol. 503. pp. 161-174.

20. Лось Д.А. // Успехи биол. химии. 2001. T. 41. С. 163-198.

21. Башарина О.В., Артюхов В.Г. // Сорбциионные и хроматографические прочессы. 2019. Т.19. №5. С.606-616.

\title{
Gas chromatographic analysis of fatty acids of maize phospholipids under various aeration conditions
}

\author{
(C) 2020 Ershova A.N. ${ }^{1}$, Tyurina I.V. ${ }^{2}$ \\ ${ }^{1}$ Voronezh State Pedagogical University, Voronezh \\ ${ }^{2}$ Voronezh State University, Voronezh
}

Lipids are crucial structural, repair, and functional component of plant cells. At the same time, phospholipids, relating to polar lipids, are the integral components of cell membranes determining together with proteins their structure and functions. Despite these facts, the number of works dedicated to oxygen deficit effect on lipid content and their fatty acid composition is very limited due to the complexity of research methods of these plant cell components. The composition and dynamic pattern of fatty acids content in phospholipids of maize seedlings exposed to short-term hypoxia (3-24h) were investigated by gas-liquid chromatography method. Lipids were extracted after probe fixation by boiling isopropanol - the mixture of hexane: isopropanol (3:2). Phospholipids from lipid fraction were evolved by the method of thin layer chromatography. Hydrolysis of phospholipids and fatty acids methylation were conducted in vacuum-sealed ampoules under $+100^{\circ} \mathrm{C}$ for 2 hours. Gas chromatographic analysis revealed that palmitic (C16:0) and linoleic (C18:2) acids dominated in phospholipids of maize seedlings (27.39 and 54.78\% of all acids respectively). In the case of oxygen deficit, within the first 3-6 hours, the content of dienoic C18:2 acid in phospholipids decreased and the unsaturation index fell from 1.15 (aeration) to 0.96 . The reduction in unsaturated acids content in phospholipids of maize seedlings under hypoxia could be driven by phospholipids destruction or by the intensification of their fatty acids' peroxidation as a result of lipoxygenases. By 24 hours of hypoxia, the content of C18:2 had been rising to the level of aerated plants probably because of synthesis enhancement. The UI of fatty acids was growing, however, it was lower than in aerated plants because of a decrease in palmitoleic (C16:1) acid from 7.74\% to $0.92 \%$ and an increase in palmitic (C16:0) acid up to $29.17 \%$. The research showed that changes in the fatty acid composition of maize phospholipids under oxygen deficit (hypoxia) become noticeable even during shortterm (3-6h) expositions and not only during expositions that lasted several days, as was previously reported. Recovery of the unsaturation level of phospholipids fatty acids' at the end of the experiment suggests that under short-term (less than $24 \mathrm{~h}$ ) oxygen deficit, mid-tolerant maize seedlings can stabilize the structure and the properties of their biological membranes, which increases their adaptation properties.

Keywords: phospholipids, fatty acids, gas-liquid chromatography, hypoxia, maize seedlings. 


\section{References}

1. Gribanov G.A., Uspekhi sovremennoy biologii, 1979, Vol. 87, No 1, pp.16-33.

2. Harwood J.L., INFORM: Int. News Fats, Oils and Relat. Mater., 1994, Vol .5, No 7, pp. 835-839.

3. Williams J.P., Mitchell K., Khan M., 1987, "Metab. Skuct. and Funct. Plant Lipids", Proceedings, 7th Int. Sym. Plant Lipids, Davis NewYork, London, pp. 433-436.

4. Popov V.N., Antipina O.V., Pchelkin V.P., Tsydendamvaev V.D., Plant Physiology, 2017, Vol. 64, No 2, pp. 109-115. DOI:10.7868/S001533031701034 Available at:www.rusplant.ru

5. Crawford R.M.M., Walton J.C., Wollen B., Proceedings of the Royal Society of Edinburg, 1994, Vol. 102B, pp. 325-332.

6. Chirkova T., Gobengishvili L., Hakala K., Physiol. Plant., 1990, Vol. 79, No 2, pp. 132135.

7. Ghenerozova I.R., Vartapetian B.B., Plant Physiol., 2005, Vol. 52, No 4, pp. 540-548.

8. Behr J.H, Bouchereau A., Berardocco S., Seal C.E. et al., Annals of Botany, 2017, Vol. 119, pp. 965-976. DOI: 10.1093/aob/mcw282. Available at: www: aob.oxfordjournals.org

9. Ershova A.N., Tyurina I.V., Sorbtsionnye $i$ khromatograficheskie protsessy, 2018, Vol. 18, No 6, pp. 927-933. DOI: https://doi.org/10.17308/sorp-

chrom.2018.18/622, Available at: www journals.vsu.ru/sorpchrom.

10.Ershova A.N. Metabolicheskaya adaptatsiya rastenij $\mathrm{k}$ gipoksii $\mathrm{i}$ povyshennomu soderzhaniyu dioksida ugleroda. Voronezh, Voronezh State Univ. Publ., 2007, 264 p.

Ершова Антонина Николаевна - профессор кафедры биологии растений и животных, д.б.н., Воронежский государственный педагогический университет, Воронеж

Тюрина Ирина Владимировна - студент, Воронежский государственный университет, Воронеж
11.Zemlyanukhin A.A., Ershova A.N., Proceedings of USSR Academy of Science, 1986, Vol. 281, No 3, pp. 762-764.

12.Brown D., Beevers H., Plant Physiol., 1987. Vol. 84, No 2, pp. 555-559.

13. Vartapetian B.B., Andreeva I.N., Generosova I.R., Annals of Botany, 2003, Vol. 91, pp. 155-173. DOI: 10.1093/aob/mcf244, Available at: www.aob.oupjournals.org

14.Fox T.C., Kennedy R.A., Rumpho M.E., Annals of Botany, 1994, Vol. 74, No 3, pp. 445455.

15.Sconfeld P., Wojtczak L., Free Rad Biol Med., 2008, Vol. 45, pp. 231-241.

16.Ershova A.N., Popova N.V., Berdnikova O.S., Plant Physiol., 2011, Vol. 58, No 6, pp. 834-843

17.Sasidharan R., Hartman S., Liu Z., Martopawico S. et al., Plant Physiol., 2018, Vol. 176, No 2, pp. 1106-1117. DOI: 10.1104/pp/17.01232 Available at: www.plantphysiol.org/cgi

18.Blokhina O., Fagerstedt K.V., Physiol. Plantarum, 2010, Vol. 138, pp. 447-462. doi:10.1111/j.1399-3054.2009.01340. Available at: www. physiol.plantarum.org

19.Ivanov I., Archives of Biochem. and Biophys., 2010, Vol. 503, pp. 161-174.

20.Los D.A., Uspekhi biologicheskoy khimii, 2001, Vol. 41, pp. 163-198.

21.Basharina O.V., Artyukhov V.G., Sorbtsionnye i khromatograficheskie protsessy, 2019, Vol. 19, No 5, pp.606-616. DOI: 10.17308/sorpchrom.2019.19/1176 Available at: www journals.vsu/sorpchrom

Ershova Antonina N. - prof., grand $\mathrm{PhD}$ (biology), department of plant and animal biology, Voronezh State Pedagogical University, Voronezh, email: aershova@vspu.ac.ru

Tyurina Irina V. - student, Voronezh State University, Voronezh 